\title{
Zelení singles: Analýza profilů environmentalistických seznamek ${ }^{1}$
}

\author{
Green Singles: The Analysis of Profiles on Dating Sites \\ for Environmentalists
}

Lukáš Kala

\begin{abstract}
This study inquires into aspects of lifestyle of the clients of environmental dating sites in the context of individualization and environmental issues. Findings are based on both quantitative and qualitative analyses of one thousand randomly selected profiles of a specific group of environmentallyfocused singles searching for partners with similar values. Dating sites for environmentalists identify their users as 'green singles'. The article presents a critical view of the environmental dimension of their lifestyles and also calls into question the stereotypical concept of 'singles,' which views them as free individuals who have voluntarily chosen a hedonistic lifestyle without regard for the environment. Discussion includes the characteristics that attest to a shared identity amongst users of these sites and an attempt to identify the motives behind their lifestyle choices.
\end{abstract}

KEY WORDS individualization, singles, environmental lifestyle, identity, online dating sites for environmentalists

\section{Úvod}

Snaha o ekologicky příznivé chování pronikla i do specifických oblastí rodinného života. Zajímavé zjištění přinesly studie zkoumající environmentální dimenze rodinných rituálů, např́iklad svateb (Kozin 2003) a pohřbů (Dobešová 2012). Poněkud stranou zájmu badatelů zůstává oblast hledání partnera, do níž se snahy o environmentálně příznivý životní způsob také promítají.

$\mathrm{Na}$ internetu můžeme nalézt desítky národních i mezinárodních seznamek, které se zaměřují na klienty s environmentálními zájmy a hodnotami. Tyto weby bychom mohli zařadit do kategorie subpopulačních seznamovacích systémů, které jsou zaměřené na určitou cílovou skupinu a vymezují se vůči mainstreamu (Finkel a kol. 2012). Jejich deklarovaným cílem je zprostředkovat seznámení lidem žijícím dlouhodobě bez partnera, kteří se zároveň hlásí k environmentálním hodnotám. Slovy zrrizovatelů seznamky Earth Wise Single patří do okruhu jejich klientů ,zeleně žijící a environmentálně odpovědní přátelé Matky Země,

Sociálni studia. Katedra sociologie FSS MU, 1/2013. S. 129-146. ISSN 1214-813X.

1 Stat’ vznikla jako součást projektu Grantové agentury ČR „Význam domova perspektivou samostatně žijících osob“, který je evidován pod číslem 13-32237S, a projektu specifického výzkumu „Ekologicky příznivé varianty životního způsobu“ MUNI/A/0764/2012. 
kteří se zajímají o lidská práva, světový mír, alternativní a holistickou medicínu či ekologické zemědělství'.2

Přestože tyto seznamky mají desítky tisíc klientů, zůstal fenomén environmentálně smýšlejících singlů badateli až doposud bez povšimnutí. Ačkoliv jejich masivní nárůst pozorujeme až v posledních letech, jejich počátky klademe do 80 . let 20. století, tedy do stejného období, kdy se singles stali předmětem výzkumu. Okruh klientů je přitom z výzkumného hlediska nesmírně zajímavý. Samotná existence environmentálně se profilujících singlů nabourává četné stereotypní představy o singles, ${ }^{3}$ jejichž životní způsob je nezř́íka popisován jako plýtvavý a životnímu prostředí škodlivý. ${ }^{4}$

Fenomén singles bývá dáván do kontextu společenských změn vyvolaných procesem individualizace (Beck a Beck-Gernsheim 2002) a druhé demografické tranzice (van de Kaa 1987). Do životního způsobu klientů zelených seznamek se tyto změny také promítly (například odložení rodiného života a realizace prostřednictvím jiných životních strategií). Projevují se však u nich také výrazné snahy o nalezení identity mimo konzumní vzorce chování (hledají nové totožnostní skupiny a environmentálně př́iznivější varianty životního způsobu), čímž se odlišují od ostatních singlů.

Prvotní úvahy nad skupinou klientů environmentálních seznamek mě dovedly k otázkám: Kdo na nich hledá partnera? Na základě čeho se jejich uživatelé ztotožňují s označením „zelený single“? Můžeme v jejich profilech nalézt doklady environmentálně příznivého životního způsobu? Domnívám se, že nejvíc nám o nich samotných prozradí to, koho hledají. $\mathrm{K}$ výzkumu přistupuji s hypotézou, že hledají svůj vlastní obraz - někoho stejně hodnotově orientovaného s podobným životním způsobem.

\section{Základní vymezení pojmů}

Fenomén singles bývá spojován s procesem individualizace, tedy s procesem nabourávání tradičních institucí industriální modernity, včetně rodiny. ${ }^{5}$ Člověk je vnímán sebou i společností jako individuum existující nezávisle na jakýchkoliv skupinách (Singly 2007; Beck a BeckGernsheim 2002 a další). Kvůli oslabení významu tradičních hodnot ${ }^{6}$ je jedinec osvobozen od sociálních omezení a vzrůstá důležitost jeho individuálních rozhodnutí a jednání (Halman

\footnotetext{
Podobně svou cílovou skupinu popisují i ostatní seznamky pro zelené singly.

Jejich př́kladem může být inzertní článek výrobce potravin Hamé: „....nechtějí s nikým sdílet společnou domácnost, a dělit se tak o podstatnou část své svobody a soukromí. Život o samotě jim v zásadě velice vyhovuje... [v]ěnují se kariéře nebo osobním zálibám... [m]ohou si dovolit výstřední koníčky... [u]žívají si klid a pohodu, nemusí se nikomu přizpůsobovat..." (anonymus 2012).

4 O plýtvavém a energeticky i materiálově náročném životě jednočlenných domácností referuje např́íklad Sanne (2002: 277).

5 Tradiční rodina byla institucí ,charakteristickou internalizovanými normami a hodnotami, které byly silně sociálně vzorovány a kontrolovány“ (Rabušic 1996: 175), zatímco současné formy soužití jsou založené na každodenních životních experimentech (Giddens 1993).

6 Za tradiční hodnoty považuji hodnoty nereflektované, přijaté na základě deontologické etiky - „,o se musi“".
} 
1996; Nevitte a Cochrane 2006). Jeho identita již není daná a může se jí zříct (Singly 2007: 35). Zároveň se však získání a naplnění identity stává úkolem se všemi negativními důsledky $\mathrm{z}$ toho plynoucími (Bauman 2004: 171).

Zásadní je vymezení pojmu singles. Přestože se o singles hodně mluví a jejich nárůstu v západních společnostech jsou věnovány četné statistiky, ${ }^{7}$ nejedná se o jasně definovanou sociální skupinu. Někteří mezi ně zahrnují osoby ovdovělé, odloučené a rozvedené (Schwartz a Scott 2010: 201), jiní je jako singles nevidí (Lamanna a Riedmann 2003: 185). Další berou za hlavní kritérium singlovství absenci dlouhodobého vztahu (Radimská a Tomášek 2003: 10) či nepř́tomnost rodičovského závazku (Možný 2002: 205). Do jisté míry může být nápomocná materiální definice singles, kdy zásadní roli hraje jejich finanční nezávislost ${ }^{8}$ (Raymo 1998). Na základě tohoto př́stupu bychom však museli za singles považovat i páry nesdílející jednu domácnost. ${ }^{9}$

Rozpory v základních atributech určujících singlovství vedou k vágnímu teoretickému zakotvení této skupiny. $V$ př́padě environmentálně zaměřených singlů je situace ještě složitější. Pokud bychom tuto skupinu hledali v populaci, museli bychom navíc definovat hranici mezi environmentálním zájmem a nezájmem. $V$ rámci tohoto výzkumu jsem proto ponechal definiční vymezení výzkumného vzorku na samotných klientech seznamek pro environmentalisty. ${ }^{10}$ Pro zjednodušení je budu označovat termínem zeleni singles, i když je zde předpoklad, že se nejedná o koherentní skupinu vyznačující se jednotnou charakteristikou.

\section{Metoda výzkumu}

Určení výzkumného vzorku předcházel výběr zelených seznamek, mezi jejichž klienty byl výzkum realizován. Vzhledem k tomu, že se na environmentálně zaměřené singly orientuje několik desítek seznamek, bylo nutné vyhledat ty, u nichž bylo možné předpokládat srovnatelnou klientelu. Prvním kritériem byla deklarovaná cílová skupina. Byly vyloučeny niche seznamky zaměřující se pouze na specifickou část zelených singlü1 (například vegetariány, ochránce zviŕă atd.). Kvưli možnosti zkreslení národními specifiky byly do vzorku vybrány pouze mezinárodní zelené seznamky. ${ }^{12}$ Dále jsem se snažil vybrat seznamky s dostatečným

7 Podle U.S. Census Bureau je ve Spojených státech amerických 99,6 milionů lidí starších 18 let $(43,6 \%)$ svobodných. V ostatních západních zemích je podíl svobodných ve společnosti sice nižší, ale přesto výrazný. Zhruba každá čtvrtá domácnost je domácností jednotlivce. Australský statistický úřad (Australian Bureau of Statistics) zjistil, že v Austrálii mají 24,4 \% takovýchto domácností, britský Národní statistický úrad (The Office for National Statistics) stanovil 28 \%, německý DESTATIS $29 \%$ a ČSÚ $27,8 \%$.

8 Kaufmann je toho názoru, že singlovství končí a pár začíná momentem pořízení společné pračky (1992: 25).

$9 \quad$ Naprríklad nové rodinné formace LAT (Living Apart Together), kdy žijí partneři každý zvlášt (Levin 2004).

10 DePaulo a Morris právě vlastní definování se singlem vnímají jako rozhodující (2005: 59).

11 Patř́ sem např́íklad Veggie Love, Veggie Connection, Veggie Romance či Animal Attraction.

12 Národní seznamky jako britská Natural Friends a Ecologist Dating, německá Gleichklang či francouzská Amours Bio byly vyloučeny. 
množstvím klientů, aby byl možný náhodný výběr. Důležitým kritériem byla podobnost cílové skupiny. Nespoléhal jsem přitom pouze na sdělení zřizovatelů, vodítkem pro mě byl i vzhled a obsah stránek. Avšak nejdůležitějším kritériem výběru byla porovnatelnost deskriptorů (věk, povolání, náboženství...) vyžadovaných po klientech a zveřejňovaných v rámci jejich profilů.

Většina zelených seznamek využívá k oslovení svých klientů podobná hesla. ${ }^{13}$ Zajímavá je i symbolika. Stránky jsou laděné do zelené a spolu se symboly lásky vždy současně vystupují symboly př́rody, nejčastěji stromy. Pokud se na stránkách vyskytuje reklama, jedná se zpravidla o upoutávku na environmentální organizace a jejich projekty (např́ílad People for the Ethical Treatment of Animals, Save Whales Again, AVAAZ či Greenpeace). Co se vzhledu týče, jsou si stránky seznamek velmi podobné.

Na základě výše popsaných kritérií byly vybrány seznamky Planet Earth Singles (dále PES), Green-Passions (dále GP), Ethical Singles (dále ES), EcoDater (dále ED) a Green Singles (dále GS). Jejich komparabilitu jsem zpětně prověřil porovnáním rozdílů mezi profily singles získanými z různých seznamek. Zjišsěné rozdíly průměrných hodnot nebyly ve většině kategorií statisticky významné.

Výběr vzorku probíhal pomocí generátoru náhodných čísel, který z každé seznamky vylosoval 100 mužských a ženských profilü ${ }^{14}$ bez ohledu na zemi pobytu. Z každé z pěti seznamek tak bylo vybráno 200 profilů, celkově 1000 . Pokud to podmínky seznamky neumožňovaly, byl použit vícestupňový náhodný výběr, při kterém byly losovány nejprve státy a posléze profily. Vzhledem $\mathrm{k}$ tomu, že se zajímám o singles, kterých se potenciálně může týkat založení rodiny, vyloučil jsem z výběru všechny klienty starší 50 let.

Obsah každého vybraného profilu byl posléze za účelem kvantitativní analýzy kódován. Byly sledovány následující kategorie: pohlaví, věk, sexuální orientace, preferovaný vztah, etnická př́ślušnost, náboženské přesvědčení, politická orientace, vzdělání, zaměstnání, životní situace, počet dětí, odhodlání mít děti, ochota k přestěhování se, stravování, tetování a piercing, domácí mazlíčci, mecenášství, aktivizmus a dobrovolnictví. Částečně vyplněné profily nebyly ze vzorku vyloučeny.

Zvlášt' jsem zaznamenával odpovědi na otevřené otázky zaměřené na popis sebe a hledaného partnera. V kontextu kategorií sledovaných kvantitativním výzkumem jsem si v textech všímal často se opakujících slov a slovních spojení. Indikátorem významnosti pro mě byla četnost výskytu určitého typu výpovědi v různých profilech. K těmto výpovědím jsem přistupoval hermeneuticky s cílem porozumět významům, které do nich klienti seznamek vložili. Sledoval jsem souvislosti, v jakých je klienti používají, což mně pomohlo porozumět jejich specifickým motivacím, jednání a postojům.

13 Pro srovnání, heslo seznamky Green Singles zní: „Najdi lásku \& zachraň planetu!“ a heslo EcoDater: „Miluj přírodně!“.

14 Vyhledávání mužů a žen zároveň nebylo možné, proto nemůžeme říct, zda by byli ve vzorku zastoupeni rovnoměrně či zda by určité pohlaví převažovalo. 
Lukáš Kala: Zelení singles: Analýza profilů environmentalistických seznamek

\section{Výsledky šetření}

Cílem bádání bylo zjistit, kdo jsou klienti seznamek pro environmentalisty a koho na těchto seznamkách hledají. Vzhledem ke specifičnosti výzkumu opírajícího se o odpovědi na otázky, které pro své účely vymysleli zřizovatelé seznamek, jsem byl metodologicky limitován. Omezil jsem se v podstatě na deskriptivní statistiku dokreslenou reprezentativními výpověd'mi klientů. Výsledky šetření strukturuji do dvou bloků podle výzkumných otázek, přitom první blok dělím do podkapitol Individualita a životní styl, Děti, Bydlení, Stravování, Zaměstnání, Politické preference, Religiozita a Aktivizmus/dobrovolnictví.

\section{Kdo jsou zelení singles?}

Náhodným výběrem jsem získal vzorek 1000 profilů zelených singlů z 58 zemí světa. Kvůli povaze výzkumného souboru jsem mohl použít pouze metody deskriptivní statistiky. Vzorek jsem podrobil frekvenční analýze v programu SPSS. Ze zjištěných četností je možné získat přibližnou představu, kdo se stává klienty mezinárodních zelených seznamek. Nejčastěji to jsou obyvatelé USA (46\% klientů), méně často pak UK (16\%) nebo Kanady (11\%), jejichž průměrný věk je 35,2 let (muži), případně 34 let (ženy). ${ }^{15}$ V̌̌tšinou se jedná o bělochy $(85,1 \%)$, dále pak o Latinoameričany $(3,6 \%)$ nebo Asiaty $(2,7 \%)$. Převažuje mezi nimi heterosexuální orientace $(95,8 \%) .{ }^{16}$ Téměř polovina z nich má vystudovanou vysokou školu $(48,8 \%) .{ }^{17}$ Ve většině př́padů pracují ve službách $(63,3 \%)$, méně často pak jako samoživitelé $(11,7 \%)$. Část $\mathrm{z}$ nich ještě studuje $(11,2 \%) .^{18}$ Většinou se nehlásí $\mathrm{k}$ žádné náboženské denominaci, ale jsou věříí (46,4 \%). Politicky jsou spíše levicově orientovaní, liberálové $(25,5 \%)$ či socialisté $(16,4 \%) .{ }^{19}$ Nejvíce z nich bydlí v samostatné domácnosti $(48,1 \%)$ nebo se spolubydlícími (29,7\%). Drtivá většina z nich žije bez dětín a ani děti nemá $(81,9 \%)$. Významná část $z$ nich by však děti mít chtěla $(80,2 \%)$. Co se vztahů týče, jsou pochopitelně sami $\left(99,7 \%\right.$ ), přitom v $87,9 \%$ př́padů byli vždycky svobodní, $9,6 \%$ je rozvedených ${ }^{21}$ či odloučených $(2,1 \%)$. Značná část z nich hledá partnera pro vážný vztah $(41,2 \%){ }^{22}$ Převažují však ti, co jim je jedno, v co se seznámení vyvine $(49,4 \%)$.

15 Nejpočetnější věkovou kategorií byla kategorie 26-34 let. Přitom musíme mít na paměti, že ze souboru byly vyloučeny osoby v post-reprodukčním věku, tedy $50+$.

16 Pouze $1,2 \%$ identifikuje svoji orientaci jako čistě homosexuální ( $0,9 \%$ gayové, $0,3 \%$ lesby), $2,7 \%$ jsou bisexuálové nebo transsexuálové.

$17 \mathrm{Z}$ toho čtvrtina studovala $\mathrm{v}$ magisterském nebo postgraduálním studijním programu. Celkově převažují o $10 \%$ absolventky nad absolventy.

18 Nejvíce studované jsou umělecké a pedagogické obory, případně přírodní vědy.

19 Více než polovina klientů své politické názory neprozradila. Přitom z těch, co se $\mathrm{k}$ svému politickému přsesvědčení nějak vyjádřili, je čtvrtina apolitických.

20 Ve společné domácnosti s dětmi, at' už ve stř́idavé péči nebo na stálo, žije jen 14,6 \% z nich.

21 Zhruba o jedno procento převažují mezi rozvedenými ženy.

22 Partnera k uzavření sňatku hledá pouze $2,8 \%$. 
SOCIÁLNÍ STUDIA 1/2013

\section{Individualita a životní styl}

Zelení singles často velmi dbají na to, aby byl jejich životní styl a veškeré jeho projevy $\mathrm{v}$ souladu $\mathrm{s}$ jejich životním způsobem. ${ }^{23}$ Módní trendy u nich naráží na neochotu nosit kožešiny, výrobky z kůže či šperky s velkou ekologickou stopou. Populární je kultura DIY a vyrábění si módních doplňků svépomocí. V profilech s chybějící fotografií, která by tyto vizuální symboly předala, většinou nechybí slovní popis vizuální identity klienta. „Nosím častěji gumáky než makeup, ve skutečnosti makeup skoro nikdy nenosím“ (Lilybee). Podobně se vyjadřuje také VeganSeeksGreenMan: „Nenosím makeup ani šaty či sukně.“ Zejména vegetariáni a vegani zdůrazňují, že jejich oblečení není z kưže, prŕípadně že je produktem ekologického zemědělství.

Dalším viditelným způsobem, kterým zelení singles vyjadřují svůj vztah ke světu, je tetování, př́ípadně piercing. Podle Le Bretona se stává viditelným znamením vnitřní ontologické změny identity. Tvrdí, že zatímco dříve tetování odkazovalo na příslušnost $\mathrm{k}$ určité skupině, dnes má potvrzovat jedinečnost jeho nositele (2002). Na základě pilotního průzkumu profilů jsem očekával, že zelení singles budou ve větší míře tetovaní. Zejména mezi klienty žijícími životním způsobem straight edge ${ }^{24}$ jsem narazil na větší množství singlů hrdých na svá tetování. Ukázalo se však, že ve vzorku je tetovaných „pouze“ $15 \%$ klientů..$^{25}$

U zelených singles můžeme pozorovat zvýšený zájem o sebe, a to jak po tělesné, tak po duchovní stránce. Velmi hojně v jejich profilech narážíme na popis jejich individuální cesty sebe-poznání a sebe-vědomí. „Skutečné a opravdové uzdravení planety nastane, až každý uzdraví sám sebe. Osobně jsem velmi zapálená do sebe-poznání, které prospívá ozdravení mé individuality“ (Moondrum). Jejich životní styl obnáší praktikování východních cvičebních a meditačních metod - jógy, tai-chi, reiki a mnohých dalších. Přitom se překvapivě často distancují od módní vlny, která klade důraz na fyzickou stránku cvičení, a odvolávají se na duchovní aspekty svého př́stupu.

\section{Děti}

Nedílnou součástí životního způsobu zkoumaných zelených singles jsou děti. Téměř každý se o vztahu k nim, z pochopitelných důvodů, vyjadřuje (zvláště pokud hledají partnera pro vážný vztah). Překvapivě nejsou děti centrem zájmu pouze u žen, ale stejně často i u mužů. Zelení singles se často stávají strýčky a tetičkami dětí svých kamarádů. Například pro Hardcoreactivist, dětmi prý přezdívaného jako „táta Jeremy“, jsou děti „smyslem života“.

23 V rámci textu rozlišujeme životní způsob, jakožto systém významných činností a vztahů, životních projevů a zvyklostí, od životního stylu, který častěji podléhá změně a nápodobě (srovnej Duffková 2005).

$24 \quad$ Straight edge je subkultura vzešlá $\mathrm{z}$ hardcore-punkové scény vymezující se zejména proti konzumaci drog a alkoholu. Environmentálním souvislostem životního způsobu straight edge se hlouběji věnoval Michoin (2011).

25 Vyplnění pole „tetováni““ v přihlašovacím formuláři zelených seznamek nebylo povinné, takže lze předpokládat, že někteří svá tetování tají. Navíc vzhledem k absenci referenční skupiny je těžké posoudit, zdali je tentovaných poměrně hodně nebo málo. 
Svou životní situaci popisuje takto: „Bydlím v lesní chatě v sousedství stejně smýšlejících kamarádů, $\mathrm{s}$ jejich dětmi mám blízký vztah. Žádné vlastní nemám, ale pro část z nich představuji otce, pro mnoho z nich strýčka.“

Oproti stereotypním představám o singles jsou pro většinu z nich děti významnou hodnotou. Založit rodinu, respektive počít dítě, by určitě chtělo $35,1 \%$ zelených singlů. Dalších $45,1 \%$ by za určitých okolností bylo ochotno o dítěti uvažovat.

Zelení singles se však vztahují $\mathrm{k}$ dětem také $\mathrm{v}$ abstraktnější rovině. Představují pro ně budoucnost a jsou často důvodem jejich aktivizmu. Buddhistická aktivistka Solei např́íklad prohlašuje: „Jsem oddaná myšlence zachovat naši planetu takovou, aby byla obyvatelná pro naše děti a všechny další druhy." $Z$ dalších výpovědí je možné usuzovat, že nejen vlastní, ale i cizí děti mohou být důvodem aktivizmu. „Přestože nemám vlastní děti, je mou vášní zachránit naši planetu pro př́rští generace“ (Nonnilucious). Kromě př́rody se i děti samy stávají předmětem dobrovolnické činnosti zelených singlů, jak dokládá např́íklad výpověd’ sunsetovertheocean: „Věřím, že máme všichni moc změnit svět. Já ji našla, když jsem jako dobrovolnice stavěla př́stř̌ešky pro zviřata nebo pomáhala zmírnit utrpení dětí nemocných rakovinou. Nikdy jsem se necítila tak štastná.“

\section{Bydlení}

Jak už bylo představeno výše, $48,1 \%$ zelených singlů žije v domácnostech jednotlivců. S ohledem na vy̌šśí spotřebu jednočlenných domácností jde o skutečnost, která mluví proti jejich označení „zelení singles“. Je však nutno dodat, že pouze 11,7 \% z nich by nebylo ochotno tento aspekt svého životního způsobu změnit. Navíc, mnozí klienti vypovídají o tom, jak šetrně ve svých domácnostech hospodaří. „Dělám, co můžu, abych snížila svou uhlíkovou stopu na minimum. Nekupuju věci do zásoby, recykluju veškeré odpadky a hledám pro ně nové využití. Snažím se udržet svůj kousek Matky Země čistý a zelený“ (Ecodivawannabe).

Poměrně často také narážíme na singles, kteří by rádi snížili svoji ekologickou stopu přestěhováním se do nějaké formy komunitního bydlení. „Dlouhodobě se vidím, jak žiju bud' v nějaké neo-urbánní komunitě nebo na venkově“ (HopeNCommunity). Jiní založení komunity přímo plánují. „Ráda bych nalezla lidi, kteří myslí na sedm generací dopředu a kteří chtějí žít jednodušší a environmentálně př́znivější život. Doufám v založení vesnice, kde budou mé děti vyrůstat ve společenství opravdového přátelství a respektu“ (sunflower). Přestože sny o životě na venkově nebo $v$ komunitě jsou poměrně častým prvkem vyskytujícím se na profilech zelených singlů, v komunitním bydlení žije pouze $7,7 \%$ z nich. ${ }^{26}$

26 Přesto se domnívám, že lze toto reintegrační tíhnutí považovat za významné. Prostřednictvím komunity stejně smýšlejících lidí, které Maffesoli (1996) označuje jako elective affinity groups, se jedinec může stát hybatelem výraznějších environmentálních změn. Skutečnost, že zelení singles po životě v komunitě touží, vypovídá jak o tom, že by rádi nalezli útočiště v nějaké pospolitosti, tak o tom, že hledají cíl, který by dal jejich životu smysl. Mnoho zelených singlů jej nalézá ve spojení se stejně smýšlejícími lidmi při práci na společném díle, jak dokládá Permawoman, která se svou komunitou založila v Londýně permakulturní zahradu. 
Daleko víc singlů žije ve spolubydlení (22\%). Zde je však silná korelace s nižším věkem. Jedná se především o postadolescenty, kteří sdílí bydlení pravděpodobně z jiných než environmentálních příčin (srovnej Heath a Cleaver 2003).

\section{Stravování}

Mezi výrazná specifika životního způsobu klientů zelených seznamek patři především jejich dieta. Ve zkoumaném vzorku jsou výrazně nadreprezentováni vegetariáni $(39,2 \%)$ a vegani $(16,2 \%){ }^{27}$ Klasickou euro-americkou stravu z konvenčních zdrojů jí pouze $29 \%$ zelených singlů. Vzhledem $\mathrm{k}$ jejich zájmu o zdraví a čistotu těla by se dalo očekávat, že právě zdravotní důvody budou hlavní motivací k odmítání masité stravy. Zdůvodnění zelených singles se však až překvapivě často odvolávají na etické př̌čciny. „Být etická je pro mě velmi důležité, kvůli tomu jsem se rozhodla být vegetariánka“ (Rosie). Zajímavým zjištěním bylo, že informaci o vegetariánství klienti sdělují nejčastěji bezprostředně poté, co projeví svůj vztah ke zviŕatům. Tato asociace je pro mě dokladem toho, že deklarované proprírodní hodnoty myslí upř́mně. „Miluji zviŕăa a každý den s nimi pracuji. Jsem vegetarián a snažím se také vyvarovat jedení vajec a mléčných výrobkü“ (leea80). Podobně pak 3385sunshine: „Respektuji Zemi a všechno živé. Byl jsem vegetariánem několik let a rok a půl jsem veganem.“

Motivace k bezmasému stravování se můžou projevit také aktivizmem jako u Nadie: „Jsem vegankou víc než 8 let a jsem ráda za to, že jsem součástí protestního projektu proti krutosti na zvírăatech.“ Své stravování berou zelení singles velmi vážně a je spíše projevem životního způsobu než životního stylu. V mnoha př́padech je spojeno se snahou o tzv. „čistý život" vycházející z hodnot „straight-edge“.

\section{Zaměstnání}

Většina zelených singles pracuje ve službách $(63,3 \%)$, nejčastěji ve zdravotnictví, školství, v nevládních neziskových organizacích a sektoru IT. Nachází se mezi nimi až zarážející množství zdravotníkủ, kteří at' už v rámci své práce nebo ve volném čase praktikují nějakou $\mathrm{z}$ forem alternativní medicíny. Léčitelé, terapeuti, maséři a bylinkáři jsou ve vzorku také hojně zastoupeni. Mezi vzdělavateli se nejčastěji vyskytují vysokoškolští pedagogové a učitelé umění. Specifickou skupinou jsou zaměstnanci nevládních organizací. V rámci vzorku můžeme nalézt zejména tři typy těchto profesí: charitativní pracovníky, ekopedagogy a profesionální aktivisty.

Další klienti $(11,7 \%)$ pracují jako živnostníci, v naprosté většině případů se jedná o umělce. Zcela výjimečně se objevují drobní podnikatelé, např́íklad majitelé vegetariánských restaurací nebo prodejci biokosmetiky. Na volné noze jsou také zemědělci, ti jsou ve vzorku zastoupeni málo $(4,6 \%)$. Nejčastěji se jedná o ekologické či permakulturní farmáře.

Mezi klienty se vyskytují také studenti $(11,2 \%)$. Zaujal mě jejich průměrný věk 29,3 let. Ten zvedají doktorští studenti, ale také lidé doplňující si současné vzdělání

27 Výsledky výzkumů zastoupení vegetariánů v populaci se pochopitelně mění s ohledem na kulturu. Např́íklad v americké dospělé populaci by mělo být 5,2 \% vegetariánů (Kalof a kol. 1999). 
o environmentální dimenzi jako ecotect: „V současné době se snažím dovzdělat. Mám umělecké vzdělání, ale zaujalo mě studium ekologické architektury a udržitelného designu. Rozjíždím kariéru v nadaci podporující ekologické stavitelství v Arizoně.“ Nekonvenčních forem vzdělávání se však účastní skoro všichni zelení singles - téměř v každém profilu se piśe o nějakém workshopu nebo kurzu, který navštěvují. „Místo studia na vysoké škole čerpám zkušenosti z života $\mathrm{v}$ ekologické vesnici, kde se učím, jak si navrhnout a postavit ekodům a jak vést malou farmu či byznys" (circles 101).

Odhodlání něco se dozvědět bývá vyslyšeno těmi, co chtějí své dovednosti předat. „Rozhodl jsem, že budu v rámci environmentálního vzdělávání v různých komunitách učit lidi jednoduchému způsobu života a primitivním dovednostem sběrače“ (HunterGatherer). Touha po samozásobitelství je velkým specifikem životního způsobu zelených singles. Velká část z nich pracuje jen na částečný úvazek nebo sezónně. „Přes léto jsem samoživitel, prospívá to jak planetě, tak mně“ (popo). Další si přilepšují tím, co ostatní vyhodí. „Dumpster diving, využití vyhozeného, soběstačnost a schopnost samostatně opravovat věci jsou pro mě extrémně důležité" (kristen). Pro všechny alternativně se živící zelené singly je velmi důležitá podpora komunity, o níž se často zmiňují.

\section{Politické preference}

Zajímavým zjištěním byla značná apolitičnost zelených singlů. Členství či podpora politických stran nejsou podstatnou součástí jejich životního způsobu - 38 \% se o politiku nezajímá. V některých případech se však nejedná o lhostejnost, ale o programový př́stup. „Nezajímám se o politiku, jsem libertarián/agorista“ (earthwindfire12). Pokud inklinují k nějakým stranám, tak jsou to strany liberální $(25,5 \%)$. Mezi preferované patř́ také socialisté $(16,4 \%)$ a pochopitelně strana zelených (10 \%). Zachovávají si však odstup. „Přestože je strana zelených nejbližší mým hodnotám, považuji se za nezávislého a vždy posuzuji program každého jejich kandidáta individuálně“ (Agnogreen).

Třídění druhého stupně také ukázalo, že většina aktivistů a dobrovolníků se zároveň zajímá o levicovou politiku. Možnou souvislost nabízí výpověd’ Veganedge: „Jsem anarcho-komunista, moje aktivistické kořeny pramení z boje za práva zviŕatat, což je má největší vášeň. Jsem také enviro-aktivista a věŕím $\mathrm{v}$ osvobození veškeré země a zotročených bytostí bez ohledu na cenu."

\section{Religiozita}

Podobně zajímavým aspektem životního způsobu zelených singlů je jejich religiozita. Příslušnost $\mathrm{k}$ tradičním církvím a praktikování tradičních věrouk je totiž spiše raritní záležitostí. Většina zelených singlů jde vlastní duchovní cestou $-46,4 \%$ z nich je věrících bez vyznání. „Baví mě se učit a poznávat různé náboženské tradice a věŕím, že je zde mnoho cest, které vedou ke stvořiteli“ (earthdreamer).

Dủležitá je pro ně spiritualita, kterou „postrádají u organizovaných náboženstvi““, jak popisuje klientka ED Katie. Spiritualitu začleňují do svého životního způsobu díky stravování, cvikům, meditaci a rituálům. Velmi časté je spojení duchovního života s léčením tělesných 
problémů. Překvapivě velké množství zelených singlů nedělá rozdíl mezi posvátným a profánním, religiozita vstupuje do jejich každodenního života. Je pro ně cestou k jejich vědomí, ke zrození autentičtějšího a celistvějšího já. Pracují s ní jako s duchovní technikou $\mathrm{k}$ dosažení osobní spokojenosti. Zavedená náboženství a věrouky (zejména východní) využívají jako zdroj inspirace ke svému individuálnímu duchovnímu rozvoji.

Na jejich duchovním životě můžeme popsat fenomén individualizace a detradicionalizace religiozity projevující se klesajícím zájmem o organizované formy náboženství a př́iklonem k neinstitucionalizovaným „neviditelným náboženstvím“ (Luckmann 1967: 103). Tradiční církve mají oproti soukromým náboženstvím malou podporu. ${ }^{28} \mathrm{Z}$ nových náboženských hnutí je oblíbené zejména neo-pohanství, ${ }^{29}$ ke kterému se hlásí 4,8 \% klientů zelených seznamek. Oproti tomu scientologové nejsou ve vzorku téměř zastoupeni $(0,3 \%)$. Domnívám se, že zelení singles vyhledávají v rámci nových náboženských hnutí ta, která umožňují hlubší prožívání vztahu člověka a přírody. Narážíme zde možná na archetypální náboženskou potřebu člověka, jak o ní píše Mircea Eliade (1994: 8), stojící proti suché vědecké ekologii a církvím uzavřeným do chrámů.

\section{Aktivizmus a dobrovolnictví}

Aktivizmus a dobrovolnictví jsou kromě vegetariánství dalším specifickým znakem zelených singlů. Podle toho, co na svých profilech tvrdí, se této činnosti věnuje 33,7 \% z nich. Není překvapivé, že se nejvíc angažují mladí lidé do 26 let (43\% z této kategorie), s přibývajícím věkem míra jejich aktivizmu klesá a v kategorii $42-50$ let se angažuje už jen $28 \%$ singlů. Jak už bylo řečeno, na míře aktivizmu se podílí i politické přesvědčení. Mezi sympatizanty socialistů je 63,2 \% aktivistů, což je dokonce víc než u strany zelených, kde jich je jen $54,7 \%$.

Důvody, proč se zelení singles angažují, jsou různé. Jako převažující motivace bych označil práva zvířat a globální problémy (např́ílad klimatická změna). „Vedu kampaň ohledně změny klimatu, protože to považuji za jednu z největších výzev pro lidstvo v historii, nehledě na to, že moje studium muselo ustoupit na druhou kolej“ (moriarty). Někdy aktivizmus u zelených singles představuje hlavní zpưsob trávení času. Pokud prostoupí hlouběji do životního způsobu, má podle mě velký identitární význam.

Identita environmentálního aktivisty je poměrně trvalá a odkazují se k ní i ti, co se již př́mým aktivizmem nezabývají. Nalezl jsem velké množství výpovědí odkazujících na aktivistickou minulost, např́iklad: „Jako aktivista a žurnalista jsem dokumentoval dopady americké politiky na životní prostréedí a obyvatele Latinské Ameriky, trénoval jsem aktivisty v technice nenásilného odporu“ (Greenmansean).

Specifickým typem klientů-aktivistů jsou ti, kteří jsou motivováni deontologicky - tedy určitou mravní povinností. Někteří takovouto povinnost vnímají jako vnitřní, přestože jejich jednání reaguje na potřebu druhé bytosti. Tento typ motivace se zpravidla vyskytuje u biofilně

28 Ke katolickému vyznání se hlásí 3,2 \% z nich a k dalším křest’anským církvím 7,8 \%. Populární je také buddhizmus $(5,4 \%)$. Nicméně je otázkou, jestli jej na Západě řadit mezi tradiční náboženství. 29 A to především kult wicca uctívající Bohyni Matku (Zemi). 
orientovaných klientů seznamek. Například aktivista GentleSpirit68 se na svém profilu několikrát vyjadřuje k tématu života: „Jsem životem fascinován... [ž]ivot je nejdůležitější lekce... Zajímá mě vše okolo života“. V souvislosti se svým aktivizmem se pak vyjadřuje následovně: „Musím se starat (zajímat se) o každou bytost, se kterou se setkám, at' už je to člověk nebo mravenec." Podobně motivovaná je buddhistka Justice4all, která bojuje za práva zviŕat prostřednictvím nenásilných a mírových kampaní. Vnější deontologické motivace mající kořeny v náboženské ideologii jsem však nepozoroval. ${ }^{30}$

Nejčastějším typem aktivizmu je dobrovolná činnost pro nějaké místní sdružení. Domnívám se, že zelení singles inklinují $\mathrm{k}$ členství v těchto organizacích také ze sociálně inkluzívních důvodů. Velmi časté je také dobrovolnictví na ekologických farmách spojené s cestováním po světě - wwoofing ${ }^{31}$. Výpovědi, především mladších zelených singlů, jako je Maggiem, se s překvapivou podobností opakují: „Mojí vášní je dobrovolnictví a aktivizmus, mým snem je cestovat. Hledám někoho, kdo by chtěl se mnou poznat svět.““

Namísto shrnutí atributů životního způsobu zelených singles představím výstižnou sebereflexi 36letého Kanad'ana vystupujícího pod pseudonymem Anarchoprimitivist. „Jsem aktivista, bývalý culture jammer a writer. Taoista, anarchista a neotribalista. Vagabund hledající skutečný domov. Miluji svobodu a nenávidím lži. Miluji děti, zviŕăa a krajinu. Někdy, dř́v než budou mé dny u konce, bych chtěl pocítit rodinnou blízkost. Chci být štastný. Nechal jsem za sebou shon města a žiju soběstačně na venkově. Nemám internet, ale bývám on-line, když se do města vracím. Také nemám trvalé zaměstnání, nestarám se o majetek. Souhlasím s Tyler Durdenem: ,Věci, které vlastníš, nakonec vlastní tebe.' Chtěl bych domov a komunitu!“

\section{Koho na zelených seznamkách hledají?}

Kvantitativním šetřením jsem zjistil, že 49,3 \% klientů je otevřeno jakémukoliv typu vztahu, $41,2 \%$ hledá pouze vážnou známost, $5 \%$ na seznamkách hledá prátele, $2,8 \%$ potenciálního manžela/manželku a $1 \%$ krátkodobý vztah. Toto zjištění nám nabízí jen částečnou odpověd’ na výše položenou otázku. Ani třídění druhého stupně však nepřineslo zajímavá zjištění. Různé kategorie zelených singlů vyhledávají v podstatě stejné typy vztahů. Není překvapivé, že nejčastěji vyhledávají vážný vztah nebo manželství starší klienti (zejména ženy), zatímco mladší jsou typu vztahu více otevření.

Kvalitativní analýza výpovědí získaných z profilů zelených singles potvrdila předpoklad, že ve většině prípadů hledají někoho podobně hodnotově orientovaného, před kým by si svůj

30 Můj výzkum neprokázal, že by se buddhisté více zabývali otázkami životního prostředí než vyznavači ostatních náboženství, jak by se mohlo zdát ze závěrů práce Zelení bodhisattvové Dušana Lužného (2000). Alespoň mezi klienty zelených seznamek se mnoho angažovaných buddhistů nenalézá. Ze všech buddhistů se dobrovolnictví nebo aktivizmu věnuje pouze $27 \%$, což je v podstatě stejně jako např́íklad u křest'anů.

31 Worldwide Opportunities on Organic Farms. 
životní způsob nemuseli obhajovat. Výpovědi některých klientů v podstatě potvrzují fenomén pozorovaný Luhmannem: „V manželství se již nehledá nereálně povýšený ideální svět, a tím méně nějaké trvalé osvědčování vášnivých citů, nýbrž základ dorozumění a společného jednání ve všem, co je pro člověka důležité“ (2002: 157). Pro představu uvádím několik reprezentativních výpovědí: „Jsem přesvědčený vegetarián, ale snažím se jíst převážně veganskou stravu. Mám rád Boha, př́rodu a všechny živé bytosti a hledám někoho, kdo to má podobněc“ (lovemystic76). „Hledám někoho, kdo rozumí motivům mého životního způsobu a chtěl by jít mou cestou“ (larimarlove). „....někoho, kdo sdílí mé hodnoty“ (emeralda). ,....kdo sdílí můj pohled na svět, mé výzvy a myšlenky...“ $(L D N)$. „...kdo sdílí můj zájem. Veganství je plus, vegetariánství nutnost“" (Aimee).

Zjistil jsem, že zejména pro vegetariány je nalezení někoho se stejným životním způsobem klíčové. Nacházíme desítky podobných formulací. Například u Jeremyho: „Jsem vegetarián a rád bych se seznámil se ženou, která má stejné zájmy a životní styl.“Ačkoliv jsou zelení singles sami, neslevují při hledání partnera ze svých hodnot. Klient ED Eco-prince hledá veganky a environmentalistky pro „,uhlíkově neutrální vztah“ a vymiňuje si: „Nekontaktujte mě, dokud nebudete znát svou uhlíkovou stopu!“ Mezi další podmínky vztahu patří, často vyžadovaná, biofilní orientace potenciálního partnera. „Musí mít rád rostliny, zviřata a př́́rodu“ (Soulcraft). Nezř́́dka se vyskytuje i negativní vymezení nepř́ipustných hodnot a životního stylu. „Neklapne to: s někým, kdo sleduje hodně TV, kdo není schopen vést vážný rozhovor déle než 5 minut, kdo nerad čte..." (televisionsux).

Ve vzorku se však vyskytují také singles hledající vztah romantické lásky, jak jej popisuje Giddens (1993). Oproti kompatibilitě hodnot a životního způsobu hledají tito klienti především spř́zzěnou duši (soul mate). Vyznačují se přesvědčením, že podmínkou manželství (př́ípadně dlouhodobého vztahu) je vzájemná přitažlivost. ${ }^{32} \mathrm{~V}$ tomto duchu se např́klad vyjadřuje klientka Aldrin: „Hledám romantického muže, se kterým bych mohla založit rodinu.“ Zajímavým zjištěním bylo, že zeleným singlům jde spíše o přitažlivost duševní než tělesnou. Chybějící údaje tělesných proporcí u většiny profilů a detailní rozpracování duševní stránky osobnosti by této domněnce nasvědčovaly. Klient $P o P o$ se $\mathrm{k}$ tomu vyjadřuje takto: „Nehledám u ženy pouze sexuální a bio-chemickou pritažlivost, ale pravé partnerství, lidskou a pravdivou komunikaci, opravdovou spirituální lásku a přitažlivost." Podobně pak Earth_buddha: „Přestože mám hodně prátel, chybí mi romantický partner, se kterým bych mohla sdílet hluboké duchovní spojení. Jeho osobní víra není důležitá.“

Právě nevyhraněnost a obecné romantické očekávaní od partnera činí tyto singles specifickými. Nejvýrazněji jsem tento postoj pocítil ve výpovědi Lilybee: „Ekoprincezna hledá ekoválečníka: ,...očekávám seznámení s někým ekologicky ctnostným, ...kdo bude chtít žít zelený, jednoduchý, čestný a intuitivně správný život...'““ Častým jevem je také touha po toleranci a akceptace jinakosti. „Nežiji jako mainstreamoví lidi, věřím ve ctnosti, soucit, ale to je všechno staromódní a nudné. Jsem taky vegetarián, další komplikace. Hledám někoho tolerantního, kdo je zároveň spokojený sám se sebou“ (Hopeless romantic). V profilech těchto zelených singlů se někdy společně s touhou po partnerovi objevuje touha změnit se a uniknout

32 Giddens v tomto směru mluví o afektivním individualizmu (Giddens 1993). 
ze současné životní situace. „Jsem připravena na hlubokou lásku, snášet dobré i zlé. Opust’me hned naše životy, usad'me se co nejdál od měst a bud'me soběstačni“" (beingoflove).

Podobnou skupinu představují ti, co romantický únik z měst podnikli, ale jsou osamocení. Jejich motivace $\mathrm{k}$ nalezení partnera hodnotím jako pragmatické. Typickým zástupcem této skupiny je ekologický zemědělec, který žije sám na farmě a hledá ženu, kterou by tento životní způsob zajímal. „V předchozím desetiletí jsem se stal farmářem. Vypadl jsem ze sociálního života, který jsem vedl $\mathrm{v}$ Torontu. Je pro mě důležité najít někoho, kdo by chtěl žít na farmě“ (Jonny). Do stejné situace se dostávají singles žijící v uzavřených komunitách bez možnosti nalézt vhodného partnera. „Žiji se svými 12 kamarády na 220 akrech v horách Západní Virginie, jsem frustrovaný z toho, že tady nemůžu najít ženu, které by nešlo jen o sociální status a peníze“ (Peiro).

Ve zkoumaném vzorku jsem narazil také na několik singles, jejichž hlavní motivací bylo nalezení partnera pro založení rodiny. Jednalo se spiše o výjimečné případy. Zatímco kvantitativní šetření ukázalo, že 35,1 \% klientů chce dítě, v kvalitativním šetření jsem nenarazil na výpovědi, které by dokládaly, že chtějí také partnera pro založení rodiny. Zelení singles se v souvislosti s dítětem o partnerovi baví jen málo, když už, tak překvapivě často zmiňují účelovost takového vztahu. Breathinglife: „Ráda bych potkala někoho, kdo by chtěl vychovávat uvědomělé děti.“" Podobně pak Claraartista: „Ráda bych s někým prrivedla na svět své děti, což byla vždycky moje priorita."

\section{Diskuze}

\section{Věrohodnost výpovědí}

Hlavním úskalím analýzy profilů zelených singles je jejich možná autostylizace. Určitý individuální greenwashing ${ }^{33}$ je sice možný, ale ve větší míře ho vylučuji. Především kvůli tomu, že téměř $44 \%$ klientů zelených seznamek vyhledává dlouhodobý vztah nebo manželství a 49 \% vážný vztah nevylučuje. Psychologické výzkumy přitom prokázaly, že pokud klient seznamek očekává setkání tváŕí v tváŕ, je ve vyplňování profilů upř́ímnější, a to i přesto, že má upř́mnost negativní vliv na jeho schopnost zaujmout potenciálního partnera (Gibbs 2006).

Nemůžeme však vyloučit určité zkreslení. Podle výzkumu Bryma a Lentona zhruba čtvrtina klientů internetových seznamek klame, nejčastěji ohledně věku (14 \%), rodinného stavu $(10 \%)$ a vzhledu (10 \%) (2001). Důvodem je očekávané klamání a přehánění ze strany ostatních a obava, že by kvưli své pravdomluvnosti byli znevýhodněni (Fiore a Donath 2004). Vzhledem k tomu, že klienti zelených seznamek hledají dlouhodobý vztah, že kladou důraz spíše na atraktivitu osobnostních rysů, stylu života, názoru a postojů, dá se očekávat vyšší míra pravdomluvnosti.

33 Klamavé jednání za účelem prezentovaní se zelenějším a environmentálně odpovědnějším než jakým jsem ve skutečnosti. 
Identita

Klienti zelených seznamek představují pestrou skupinu rozdílně motivovaných singles s odlišným životním způsobem. Přesto hledají partnera na stejných stránkách a identifikují se všeobecným označením zelený singl. Co však odlišuje zeleného singla od ostatních singles? Na základě čeho staví svoji identitu?

V rámci výzkumu jsme narazili na několik ,zelených kulturních kódư“ ${ }^{34}$ které zkoumaní singles sdílejí a které mohou odkazovat k určité kolektivní identitě. Styl oblékaní vyznačující se oblibou pestrých barev (batiky), khaki, přírodních ozdob a symbolů odkazujících k subkultuře hippie by stál za samostatnou analýzu profilových fotografií. Mezi další společné kulturní kódy patří pobývání v přírodě, deklarovaná touha po životě na venkově či přímo život na venkově, specifické praktiky nakupování, umělecké ambice, absence televize či auta. Charakteristické jsou zejména projevy asketických hodnot (různá sebeomezení) a snahy o nezávislost na systému: samozásobitelství, pěší nebo cyklistická doprava, neplacené zaměstnání. Mnoho klientů zelených seznamek staví svou identitu na „dobrovolné skromnosti“ a „nematerialistickém př́stupu k životu“ (Katelovescosmos). Podobně Glenn: „Jsem oddaný jednoduchému životu, soběstačnosti a zemitému životu zahrádkáře, rybáře a lovce.“

Kulturní kódy sdílené zelenými singly se $\mathrm{v}$ zásadě shodují s těmi, které identifikoval Horton u environmentálních aktivistů (2003: 65-70). Ve shodě s jeho závěry bych také já za hlavní distinktivní rys zelené identity označil stravování (2003: 70). Zatímco některé kulturní kódy, jako nevlastnění auta či televize, mají spíš epizodický charakter, být vegetarián nebo vegan je pro identitu zeleného singla určující. Oproti Hortonovi však nemůžeme potvrdit, že by aktivizmus koreloval s vegetariánstvím. Bezmasé stravování patří k životnímu způsobu zelených singlů např́č všemi kategoriemi. ${ }^{35}$

Zejména na základě svých specifických stravovacích návyků se vymezují vůči mainstreamu. U vegetariánů a veganů můžeme nejsnáze popsat Baumanovo dichotomní dělení světa na „my“ a „oni“ (1996: 44). Pro ilustraci uvedeme poměrně ostře znějící stanovisko LDN: „Jsem tvrdý oponent speciesismu. Jsem unaven z lidí, kteří ignorují moje vysoké etické standardy. Nechci se setkávat s masožravci, naopak bych rád potkal lidi, kteří sdílí moje názory.“ Identita vegetariána a vegana je pro ně natolik důležitá, že ji většinou zohlední i ve volbě přezdívky, pod kterou se na zelených seznamkách prezentují - např́íklad Anastasiavegan, Straight Edge Vegan či Mindfull vegan soul.

Ve svých profilech klienti používají nejen identitu podtrhující přezdívky, ale také ustálená spojení, o kterých se domníváme, že mají povahu jazykových kódů. Jejich rozbor není předmětem našeho výzkumu, nicméně může mnoho napovědět o povaze identity zelených singlů. Domnívám se, že použití některých slov a slovních spojení (jako Matka Země) je sémanticky prázdné, ale hraje zástupnou identitární úlohu. Sociolingvistická analýza profilů zelených singles by tak mohla přinést další zajímavá zjištění.

34 Tento termín poprvé použil Horton (2003) v rámci svého výzkumu identity mezi zelenými aktivisty, a navázal tak na Bourdieuho „kulturní kódy“.

35 Výrazný rozdíl se projevil pouze v porovnání politického přesvědčení a stravy. Z neznámých důvodů je nejvíce vegetariánů a veganů mezi socialisty (65\% z nich) - pro srovnání sympatizanti strany zelených jsou vegetariány ve $43 \%$ př́padů. 


\section{Kvalitativní individualizace}

Proces formace identity tak, jak jej chápe Melucci (1996: 30-31), není jen výslednicí našich získaných nebo zděděných vlastností, ale produktem naší vědomé akce a výsledkem naší sebereflexe. Domnívám se, že identita zelených singles postavená na individuálně zvolených proenvironmentálních hodnotách může být tedy projevem kvalitativní individualizace, jak o ní pojednává Librová (2010: 142). Poznání společenských a ekologických rizik umožňuje zeleným singlům redefinovat vzorce jednání a žití (Beck 1994: 59-61) a projevuje se autonomii rozhodování (Lukes 2006). Odmítnutí konzumu a potřeba prezentovat se jako někdo se specifickým životním zpo̊sobem je zeleným singlům vlastní. Jejich snaha o převzetí odpovědnosti za svůj životní způsob, případně za určitý environmentální problém, je pro mě dokladem toho, že proces individualizace společnosti může, vedle environmentalisty zdůrazňovaných negativních důsledků, přinášet i efekty životnímu prostředí příznivé.

\section{Proč jsou singles?}

Důvody, proč jsou klienti zelených seznamek až doposud singles, jsou diskutabilní. Za nejpravděpodobnější vysvětlení považuji jejich specifický životní zpo̊sob a hodnoty. $\mathrm{K}$ tomuto přesvědčení mě vedou výpovědi typu: „Žít skutečně odpovědným životem je téměř nemožné, pokud nemáte podporu rodiny a přátel. Proto se snažím najít někoho, kdo bude sdílet mé hodnoty a pro koho nebudu jen fundamentalistka“" (Lerochka). Z citace je patrné, že životní způsob této klientky není ostatními bezproblémově přijímán. Implicitně z ní vyplývá také důvod jejího osamocení a zároveň odhodlání opustit své singlovství, avšak se zachováním současného životního způsobu. To, že jsou hodnoty významným limitujícím faktorem při hledání partnera, dokládají i jiné výzkumy (srovnej Tomášek 2006).

Hlavní problémem jsou podle mě vztahy, které hledají. Ze zjištění vyplývá, že sice hledají dlouhodobý vztah, zároveň však pouze takový, který je bude naplňovat. Podle BawinLegros mají pro singles vztahy, jejichž prostřednictvím by měla být naplněna a potvrzena individualita, kardinální význam a stávají se individualizačním projektem samy o sobě (2004: 241-250). V profilech zelených singlů je vztah často pojímán samoúčelně, jako prostředek k dosažení sebe-poznání. „Co se hledá jako láska, co se hledá v intimních vztazích, bude tedy v první řadě validita sebeprezentace“ (Luhmann 2002: 170). Spíše než romantickou lásku hledají lásku spoluplynouci ${ }^{36}$ (Giddens 1993). KindredSoul se např́iklad ptá svého hypotetického partnera: „Taky chápeš romantický vztah jako cestu osobního růstu, primárně jako zrcadlo poznání sebe sama a ne druhé osoby?“ Jejich životní způsob a okruh lidí, ve kterém se pohybují, se jim pak logicky stávají limitujícím faktorem v nalezení žádoucího vztahu.

Diskutabilní je také míra dobrovolnosti toho, že jsou singles. Přestože dobrovolně volí svůj životní způsob, jsem toho názoru, že jsou singles nedobrovolně. ${ }^{37}$ Přizpůsobením se mainstreamu by možná zvýšili svou šanci na seznámení, ale ztratili by svou reflexivně

36 Confluent love - vztah postavený na jejím základě trvá, pokud přináší užitek (naplnění).

37 Peter Stein by je pravděpodobně označil za ,nedobrovolně dočasné“ př́ípadně „nedobrovolně trvalé“" (1981). 
konstruovanou identitu - tedy sebe samotné. Jejich neochota ke kompromisům ve vztazích je vzhledem ke křehkosti jejich identity pochopitelná.

\section{Závěr}

Tato práce je shrnutím části výsledků kvantitativně-kvalitativního výzkumu zaměřeného na profily klientů environmentalistických seznamek. Předložená studie jako první přináší pohled na specifickou skupinu lidí, kteří se identifikují s označením „,zelený single“.

Cílem této práce bylo popsat, kdo tyto seznamky využívá a koho na nich hledá. Zjistil jsem, že s největši pravděpodobností se jedná o lidi, kteří sdílejí podobné proenvironmentální hodnoty. Společné rysy vykazuje také jejich životní způsob a jeho projevy v životním stylu (móda, trávení volného času apod.). Přestože téměř polovina $\mathrm{z}$ nich bydlí $\mathrm{v}$ domácnostech jednotlivců, snaží se žít ekologicky šetrně. Inklinují ke sdílení předmětů, samozásobitelství, nižší spotřebě a ani ideál komunitního bydlení jim není cizí. Absence rodinných závazků jim dovoluje se plně věnovat aktivitám, o nichž se domnívají, že jsou príiznivé životnímu prostředí a že vedou k jeho zachování. Zároveň jim umožňuje svobodnou volbu zaměstnání bez ohledu na časovou náročnost a výdělek.

Určité prvky tohoto životního způsobu se pak projevují při konstruování jejich identity. Jedná se zejména o vegetariánství, veganství a aktivizmus, na které kladou ve svých profilech obzvlášt' velký důraz a na jejichž základě se vymezují nebo identifikují s ostatními. Pro mnohé $\mathrm{z}$ nich je pak klíčové nalézt podobně hodnotově orientovaného partnera, který by byl ochoten prijimout jejich životní způsob.

Dosavadní zjištění mě vedou $\mathrm{k}$ přesvědčení, že singlovství klientů zelených seznamek je pravděpodobně důsledkem jejich životního způsobu. Starost o životní prostředí se v jejich př́ipadě nepř́imo stává překážkou úspěšného partnerského života.

Při interpretaci výsledků je třeba vzít $v$ úvahu limity výzkumu (otázky byly formulovány zřizovateli seznamek) a možnosti autostylizace klientů. Představená analýza poskytuje pouze základní vhled do této problematiky a pro detailnější porozumění fenoménu zelených singles by bylo třeba provést hlubší kvalitativní šetření opírající se o cíleně pokládané otázky.

\section{Literatura}

ANONYMUS. Život single? Život bez problémů! Vlasta, 2012, č. 37, s. 25. ISSN 0139-6617.

BAUMAN, Zygmunt. Individualizovaná společnost. 1. vyd. Praha: Mladá fronta, 2004. ISBN 80-204-1195-X.

BAUMAN, Zygmunt. Myslet sociologicky: netradiční uvedení do sociologie. 1. vyd. Praha: Sociologické nakladatelství, 1996. ISBN 8085850141.

BECK, Ulrich a Elisabeth BECK-GERNSHEIM. Individualization: Institutionalized Individualism and its Social and Political Consequences. 1. vyd. London: SAGE Publications, 2002. ISBN 0-761-96112-7.

BECK, Ulrich, Anthony GIDDENS a Scott LASH. Reflexive Modernization: Politics, Tradition and Aesthetics in the Modern Social Order. Cambridge: Polity Press, 1994. ISBN 0745612784. 
BRYM, Robert J. a Rhonda L. LENTON. Love Online: A Report on Digital Dating in Canada [online]. 2003 [cit. 2012-20-09]. Dostupné na: http://www.bestsoftworks.com/docs/loveonline.pdf.

DePAULO, Bella M. a Wendy L. MORRIS. Singles in Society and in Science. Psychological Inquiry, 2005, roč. 16, č. 3, s. 57-83. ISSN 1047-840X.

DOBEŠOVÁ, Blanka. Až umřu, zasad'te na mně jabloň. Environmentální a společenské přinosy prírodního pohřebnictví. Diplomová práce. Brno: Masarykova univerzita, Fakulta sociálních studií, Katedra environmentálních studií, 2012.

DUFFKOVÁ, Jana. Životní způsob/životni styl a jeho variantnost. Praha: MČSS při AV ČR, 2005. ISBN 80-7308-131-8.

ELIADE, Mircea. Posvátné a profánní. 1. vyd. Praha: Česká křest’anská akademie, 1994. ISBN 8085795116.

FINKEL, Eli a kol. Online Dating: A Critical Analysis From the Perspective of Psychological Science. Psychological Science in the Public Interest, 2012, roč. 13, č. 1, s. 3-66. ISSN 1539-6053.

FIORE, Andrew, T. a Judith DONATH. Online Personals: An Overview [online]. 2004 [cit. 2012-20-09]. Dostupné na: http://smg.media.mit.edu/papers/atf/chi2004_personals_short.pdf.

GIDDENS, Anthony. The Transformation of Intimacy: Sexuality, Love and Eroticism in Modern Societies. 1. vyd. Palo Alto: Stanford University Press, 1993. ISBN 0804722145.

GIBBS, Jennifer L. a kol. Self-Presentation in Online Personals: The Role of Anticipated Future Interaction, Self-Disclosure, and Perceived Success. Communication Research, 2006, roč. 33, č. 2, s 152-177. ISSN 1552-3810.

HALMAN, Loek. Individualism in Individualized Society? Results from the European Values Surveys. International Journal of Comparative Sociology, 1996, roč. 37, č. 3-4, s. 195-214. ISSN 0958-9287.

HEATH, Sue. Peer-Shared Households, Quasi-Communes and Neo-Tribes. Current Sociology, 2004, roč. 52, č. 2, s. 161-179. ISSN 0011-392.

HORTON, Dave. Green Distinctions: The Performance of Identity among Environmental Activists. Sociological Review, 2004, roč. 51, č. 2, s. 63-77. ISSN 1467-954X.

KAUFMANN, Jean-Claude. La trame conjugale: analyse du couple par son linge. 1. vyd. Paris: Nathan, 1992. ISBN 2091904066.

KALOF, L. a kol. Social Psychological and Structural Influences on Vegetarian Belief. Rural Sociology, 1999 , roč. 64, č. 3, s. 500-511. ISSN 0036-0112.

KOZIN, Michelle. Organic Weddings: Balancing Ecology, Style and Tradition. 1. vyd. New Society Publishers, 2003. ISBN 0865714967.

LAMANNA, Mary Ann a Agnes RIEDMANN. Marriages and Families: Making Choices in a Diverse Society. 11. vyd. Belmont: Wadsworth Publishing, 2010. ISBN 1111726434.

LUHMANN, Niklas. Láska jako vášeň. Paradigm lost. 1. vyd. Praha: Prostor, 2002. ISBN 8072600680.

LE BRETON, David. Signes d identité: Tatouages, piercing et autres marques corporelles. 1. vyd. Paris: Métailié, 2002. ISBN 2864244268.

LEVIN, Iren. Living Apart Together: A New Family Form. Current Sociology, 2004, roč. 52, č. 2, s. 223-240. ISSN 0011-392.

LIBROVÁ, Hana. Individualizace v environmentální perspektivě: sociologické rámovaní mění pohled a plodí otázky. Sociologický časopis, 2010, roč. 46, č. 1, s. 125-152. ISSN 0038-0288.

LUCKMANN, Thomas. The Invisible Religion. 1. vyd. New York: Macmillan, 1967. ISBN 0025767003.

LUKES, Steven. Individualism. 1. vyd. Colchester: Basil Blackwell, ECPR Press, 2006. ISBN 0-954-79666-7.

LUŽNÝ, Dušan. Zeleni bódhisattvové: sociálně a ekologicky angažovaný buddhismus. 1. vyd. Brno: Masarykova univerzita, 2000. ISBN 802102464x. 
MAFFESOLI, Michel. The Contemplation of the World: Figures of Community Style. 1. vyd. Minneapolis: University of Minnesota Press, c1996. ISBN 081662688x.

MELUCCI, Alberto. The Playing Self: Person and Meaning in the Planetary Society. 1. vyd. Cambridge: Cambridge University Press, 1996. ISBN 0521564018.

MICHOIN, Jan. Fenomén straight edge v environmentálnich souvislostech, se zaměřením na oblast střední a východni Evropy. Diplomová práce. Brno: Masarykova univerzita, Fakulta sociálních studií, Katedra environmentálních studií, 2011.

MOŽNÝ, Ivo. Sociologie rodiny. 2. uprav. vyd. Praha: Sociologické nakladatelství, 2002. ISBN 8086429059.

NEVITTE, Neil a Christopher COCHRANE. Individualization in Europe and America: Connecting Religious and Moral Values. Comparative Sociology, 2006, roč. 5, č. 2-3, s. 203-230. ISSN 1569-1330.

RAYMO, James, M. Later Marriages or Fewer? Changes in the Marital Behaviour of Japanese Women. Journal of Marriage and the Family, 1998, roč. 60, č. 4, s. 1023-1034. ISSN 1741-3737.

RABUŠIC, Ladislav. O současném vývoji manželského a rodinného chování v České republice. Demografie, 1996, roč. 38, č. 3, s. 173-180. ISSN 0011-8265.

RADIMSKÁ, Radka a Marcel TOMÁŠEK. Singles - nový životní styl a jeho genderová specifika v České republice. Gender, rovné př́ležitosti, výzkum, 2003, č. 1-2, s. 10-12. ISSN 1213-0028.

SANNE, Christopher. Willing Consumers - Or Locked-in? Policies for a Sustainable Consumption. Ecological Economics, 2002, roč. 42, č. 1-2, s. 273-287. ISSN 0921-8009.

SINGLY, Francois. La lien familial en crise. 1. vyd. Paris: Presses de l'Ecole normale supérieure, 2007. ISBN 978272880395.

SCHWARTZ, Mary Ann a Barbara M. SCOTT. Marriages and Families: Diversity and Change. Upper Saddle River, NJ: Prentice Hall/Pearson, 2010. ISBN 978-0-205-68314-7.

STEIN, Peter J. Understanding Single Adulthood. In Stein, Peter J. Single Life: Unmarried Adults in Social Context. New York: St. Martins's Press, 1981, s. 9-20. ISBN 0312725973.

TOMÁŠEK, Marcel. Singles a jejich vztahy; kvalitativní pohled na nesezdané a nekohabitující jednotlivce v České republice. Sociologický časopis, 2006, roč. 42, č. 1, s. 81-105. ISSN 0038-0288.

VAN DE KAA, Dirk. J. Europe's Second Demographic Transition. Population Bulletin, 1987, roč. 42, č. 1, s. 1-47. ISSN 0032468X.

\section{Autor}

Lukáš Kala je doktorand na Katedře environmentálních studií FSS MU, kde je také zaměstnán jako asistent. Zabývá se výzkumem singles a jejich životního způsobu. Zajímají ho environmentální aspekty procesu individualizace. Externě spolupracuje na tvorbě didaktických a metodických materiálů s Lipkou - školským zařízením pro environmentální vzdělávání. Kontakt:231119@mail.muni.cz. 